\title{
Psychological Factors Influencing on the Motivation to Study of Students of TEI
}

\section{Factores psicológicos que influyen en la motivación para estudiar de los estudiantes de TEI}

\author{
Iryna $\mathrm{V}$. Aprielieva* \\ Kharkiv Humanitarian Pedagogical Academy, Kharkiv, Ukraine \\ ORCID: https://orcid.org/0000-0002-3012-7630 \\ Viktoriia A. Demchenko \\ Kharkiv National University of Radio Electronics, Kharkiv, Ukraine \\ ORCID: https://orcid.org/0000-0002-8531-3692 \\ Anastasiia V. Kovalevska \\ Administration under the President of Ukraine, Odesa, Ukraine \\ ORCID: https://orcid.org/0000-0002-1031-5546 \\ Tetiana Yu. Kovalevska \\ Odessa I.I. Mechnikov National University, Odessa, Ukraine \\ ORCID: https://orcid.org/0000-0002-5956-2599

\section{Tetiana S. Hladun} \\ M.P. Dragomanov National Pedagogical University, Kyiv, Ukraine \\ ORCID: https://orcid.org/0000-0002-0231-1238
}

Odesa Regional Institute for Public Administration of the National Academy for Public

Received 09-08-20 Revised 10-10-20

Accepted 20-12-21 On line 02-12-21

*Correspondence

Email: aprielieva5839@ubogazici.in
Cite aso:

Aprielieva, I.V., Demchenko, V.A., Kovalevska, A.V., Kovalevska, T.Y., \& Hladun, T.S. (2021). Psychological Factors Influencing on the Motivation to Study of Students of TEI. Propósitos y Representaciones, 9(SPE2), e993. Doi: http://dx.doi.org/10.20511/pyr2021.v9nSPE2.993

(C) Universidad San Ignacio de Loyola, Vicerrectorado de Investigación, 2021. 


\section{Summary}

The importance of psychological factors is manifested in the ability of students to acquire knowledge, gaining skills, perception of educational information, attitude to others, mutual understanding with people around. Taking this into consideration, the purpose of the academic paper is to study the basic aspects of the development of teachers' professional competence in the context of transformational processes in education. Such methods as: theoretical analysis, description, comparison, synthesis, grouping, measurement, observation and experiment, have been used in order to achieve the purpose and objectives outlined in the academic paper. It has been established that the motivation of students to carry out educational and professional activities is a set of psychological factors, through the influence of which the interconnection between the motivation and desire of the student to study is conducted. In the course of the investigation, it has been found that the influence of psychological factors is quite effective in the case of motivating students to study. It has been proven that increasing the motivation of students to study is possible through: a common learning environment in the students' collective; students' participation in discussions, conferences, competitions; work in groups; application of innovative technological methods of studying educational material.

Keywords: motivation to study, tertiary educational institutions, self-discipline, thinking. Resumen

La importancia de los factores psicológicos se manifiesta en la capacidad de los estudiantes para adquirir conocimientos, adquirir habilidades, percepción de la información educativa, actitud hacia los demás, entendimiento mutuo con las personas que lo rodean. Teniendo esto en cuenta, el propósito del trabajo académico es estudiar los aspectos básicos del desarrollo de la competencia profesional de los docentes en el contexto de los procesos de transformación en educación. Métodos tales como: análisis teórico, descripción, comparación, síntesis, agrupamiento, medición, observación y experimentación, se han utilizado para lograr el propósito y los objetivos descritos en el trabajo académico. Se ha establecido que la motivación de los estudiantes para realizar actividades educativas y profesionales es un conjunto de factores psicológicos, a través de cuya influencia se lleva a cabo la interconexión entre la motivación y el deseo del estudiante por estudiar. En el transcurso de la investigación se ha encontrado que la influencia de factores psicológicos es bastante efectiva en el caso de motivar a los estudiantes a estudiar. Se ha demostrado que es posible aumentar la motivación de los estudiantes para estudiar mediante: un entorno de aprendizaje común en el colectivo de estudiantes; participación de los estudiantes en discusiones, conferencias, concursos; trabajo en grupos; aplicación de métodos tecnológicos innovadores de estudio de material educativo.

Palabras clave: motivación para estudiar, instituciones de educación terciaria, autodisciplina, pensamiento. 


\section{Introduction}

Obtaining higher education by students is a rather complex process, which is influenced by many factors, including psychological ones. The importance of psychological factors is manifested in the ability of students to acquire knowledge, gaining skills, perception of educational information, attitude to others, mutual understanding with people around (Kostromina \& Dvornikova, 2016). It should also be noted that psychological factors affect the motivation and encouragement of students to study, which, in turn, is an important aspect of improving academic performance among students of tertiary educational institutions. Taking this into account, a position arises, according to which there is a close interconnection between the motivation for the implementation of students' educational and professional activities and a complex of psychological factors, influencing motivation (Kortukova et al., 2020).

Herewith, modern practice shows that currently there are many ways to motivate students to study, one of which is based on investigation of psychological factors and determining their impact on the process of obtaining higher education by students (Mihaela, 2015; Skydan, 2009). It should also be noted that psychological factors do not always have a positive effect on the process of increasing students' motivation. Thus, the best pedagogical experience reveals a number of cases when psychological factors are substantial reasons for not graduating from tertiary educational institutions due to addiction, fear of failure, depression. However, nevertheless, as studies show, the positive influence of psychological factors on students' motivation to study largely exceeds the negative influence (Skydan, 2011).

In light of this, the purpose of the academic paper is to study the psychological factors influencing on the students' motivation to study at tertiary educational institutions. In order to implement the purpose outlined, the research article provides for the achievement of a number of objectives, namely:

- $\quad$ To reveal the theoretical principles of the influence of psychological factors on the students' motivation to study at tertiary educational institutions, in particular: to consider the students' motivation to study at tertiary educational institutions as an important psychological and pedagogical problem; to investigate the issue of motivation of educational and professional activities of students of tertiary educational institutions; to consider the psychological factors influencing the students' motivation to study at tertiary educational institutions; to analyze the ways to increase the students' motivation to study at tertiary educational institutions; to consider psychological factors influencing the level of students' academic performance at tertiary educational institutions; to consider motivation to study in the context of an important aspect of critical thinking among students of tertiary educational institutions.

To present practical examples of the influence of psychological factors on the students' motivation to study at tertiary educational institutions as a result of studying questionnaires and surveys of students regarding determining their position, which psychological factors motivate them to study (based on research conducted at the University of Guilan (Iran), the Interior School of Sabah Division (Malaysia), Guaymas, Sonora (Mexico), National Academies of Sciences, Engineering, and Medicine (the United States), Inholland University of Applied Sciences (the Netherlands)).

Based on the results of the investigations conducted, to summarize the general classification of psychological factors, influencing the motivation of students to study at tertiary educational institutions.

\section{Literature Review}

The theoretical fundamentals of the influence of psychological factors on the students' motivation to study at tertiary educational institutions are currently presented in the works of numerous 
scientists. In particular, A. Siljvejstr and M. Mokljuk (2014) consider the students' motivation to study at tertiary educational institutions as an important psychological and pedagogical problem. According to the results of the investigations conducted, scientists have concluded that the tactics and training strategy, correctly selected by teachers, influence on students' positive effect in the context of their acquiring of educational material. At the same time, no less important in this context is the organization of students' studying activities, namely the choice of learning methods and techniques (Myronets et al., 2020).

The scientist V. Meljman (2015), having studied the problems of motivation of educational and professional activities of students of tertiary educational institutions (TEI), identifies a number of psychological factors influencing the increase of the students' motivation and encouragement to study. Consequently, according to the scientist's viewpoint, psychological influence factors are divided into:

- $\quad$ personal (in particular, it is the motivational structure of personality, the student's desire for self-fulfilment and self-expression, creativity, personal leadership, psychological and personal health);

professional (the level of motivation to carry out professional activities, the student's vision of himself as a professional, the attitude to the features of further professional activity);

psychological and pedagogical (features of motives to study, the level of arranging of students' learning activities, features of traditional, innovative and pedagogical methods, the level of professionalism of teachers of tertiary educational institutions, features of students' educational activities, in particular, including the conditions under which the educational process takes place);

social-psychological (features of the educational and professional environment, features of the pedagogic environment, social-psychological climate in the students' collective and the relationship between teachers and students).

In addition, V. Meljman (2015) emphasizes that the motivation to carry out educational and professional activities by students includes a set of psychological factors, through the influence of which the interconnection between motivation and desire of the student to study takes place. At the same time, K.O. Chechelj (2011) identifies such psychological and pedagogical factors influencing the motivation of students to study, as:

- $\quad$ the level and state of the relationship between the teacher and the student;

- application by the teacher of non-traditional methods and forms of organization of research activities for students in the educational process;

- the level of preparation of students and teachers to participate in research activities;

- features of stimulation and encouragement of students to participate in research activities, which are used by the teacher;

- $\quad$ the ability of teachers to promote self-development, creative implementation and self-fulfillment of students.

Along with this, K.O. Chechelj (2011), in the context of studying the influence of psychological and pedagogical factors on the motivation of students to study, obtaining education at the tertiary educational institution, the psychological direction, conducts an author's survey regarding the position of students. The results of the survey of students-psychologists' positions show that a significant proportion of surveyed students, conducting the academic research work at tertiary educational institution, correlate it at the level of creative work (this position was supported by $37 \%$ of surveyed students). $26 \%$ of the surveyed students supported the connection of the academic research work to the method of self-fulfillment (Vinichenko et al., 2018). 
At the same time, general recognition as an obligatory element of performing academic research work was supported only by $20 \%$ of the surveyed students. As regards to information on students' participation in academic research activities, only $22 \%$ of the total number of surveyed students confirmed their participation in academic research activities, conducted by the institution where they receive higher education. In the matter of the basic reasons that prevent students from being engaged in academic research activities, $60 \%$ of the total number of surveyed students have said that it is a lack of interest, $12 \%$ of surveyed students have noted their non-participation in academic research work due to lack of time for investigations and only 5\% of respondents have noted that there is no reward for performance of academic research activities, therefore, they don't take part in it (Chechelj, 2011). W.T. Beharu (2018), in the course of studying the influence level of psychological factors (including self-efficacy, motivation, test anxiety and stress) on the level of success of students at tertiary educational institutions, has stated that there is a significant interconnection between student self-efficacy and internal motivation. Correlation analysis conducted by the scientist also testifies to the presence of a strong interconnection between the level of stress and internal motivation of students.

K.I. Fomenko (2015) in his own study investigates the correlations between indicators of motivational factors and students' self-attitude to studying. The results of correlation analysis show that:

there is a strong interconnection between the quest for excellence (an indicator of hubristic motivation) with such indicators of students' self-attitude as conflict, openness and intrinsic value;

there is a strong interconnection between the desire for superiority (indicator of hubristic motivation) with such indicators of students' self-attitude as self-perception, intrinsic value, self-adherence and an ego-alter theory, however, the lack of interconnection is observed with indicators of conflict and self-accusation;

- there is a strong interconnection between the motivation for success (indicator of motives of social-psychological activity of students) with such an indicator of students' selfattitude as openness, however, there is no interconnection with the indicator of an ego-alter theory;

there is a strong interconnection between the motivation to power (indicator of motives of social and psychological activity of students) with such indicators of students' selfattitude, as openness, intrinsic value and self-adherence;

there is a strong interconnection between the affiliative motivation (indicator of the motives of students' social-psychological activity) with such an indicator of students' selfattitude as proneness to conflict, however, there is no interconnection with the indicators of selfadherence, self-confidence and self-management;

there is a strong interconnection between the communicative motive (indicator of students' motivation to study) with such an indicator of students' self-attitude as intrinsic value, self-management and self-confidence;

there is a strong interconnection between the motive of prevention (indicator of students' motivation to study) with such an indicator of students' self-attitude as self-adherence and self-perception;

there is a strong interconnection between the motive of prestige (indicator of students' motivation to study) with such an indicator of students' self-attitude as self-adherence and self-management;

there is a strong interconnection between the professional motive (indicator of students' motivation to study) with such an indicator of students' self-attitude as openness, selfmanagement and self-confidence, however, there is no interconnection with the self-accusation indicator; 
there is a strong interconnection between the motive of creativity (indicator of students' motivation to study) with such an indicator of students' self-attitude as intrinsic value, and an ego-alter theory;

there is a strong interconnection between learning and cognitive motives (indicator of students' motivation to study) with such an indicator of students' self-attitude as openness and self-management;

there is a strong interconnection between social motives (indicator of students' motivation to study) with such an indicator of students' self-attitude as self-management and selfperception.

S.V. Ponikarovsjka (2011), considering the psychological factors influencing on the education of students of tertiary educational institutions, notes that they play a decisive role in the educational process, as they affect the success of students. According to the scientist's viewpoint, special abilities, social intelligence, general intelligence and creativity have a significant impact on the results of students' acquisition of knowledge, skills and abilities. The team of scientists M.I. Ullah et al. (2013) in their own study note that motivation is one of the important aspects of critical thinking among students of tertiary educational institutions. The researchers have also come to conclusion that the students' motivation to study at tertiary educational institutions can be increased in the following ways, namely: encouraging students to discussion; formation of a common learning environment in the students' collective; work of students in small groups, etc. In addition to the above mentioned, the scholars have proposed to increase the students' motivation to study through the use of innovative learning practices, as well as due to the provision of a favorable learning environment (Ullah et al., 2013; Khalimon et al., 2019).

G. Hassan (2020), studying the factors that influence the students' motivation to study at tertiary educational institutions, argues that students who are more motivated to study are mostly goal-oriented persons. G.M. Alam et al. (2010) also investigate the influence of psychological factors on students' motivation to study. According to the results of the study, researchers have come to conclusion that the following factors have a significant impact on students' performance in the context of obtaining higher education, namely: the proper distribution of time, concentration, stress, anxiety and consultation (relationships) with teachers (educators). Scientists K.C. Kadosh and G. Staunton (2019) in their own study analyze various psychological factors, the impact of which is significant on the educational process (for example, the study of neurosafety direction). From the viewpoint of scientists, the study of the influence of psychological factors on the educational process will provide an opportunity to properly understand the psychological variables (for example, mood and motivation), which students experience in the context of their obtaining education at tertiary educational institutions.

L. Budianto (2010), in the course of investigating the influence of psychological factors on the study of a foreign language by students (for example, mastery of English), states that psychological conditions significantly influence on the process of mastering a foreign language by students. In addition to psychological conditions, the researcher also identifies such factors as attitude, motivation, anxiety and ability, because it is the influence of the above mentioned factors significantly affects the outcome of students' mastering a foreign language. In turn, Q.M. Malaspina (2018), studying the influence of psychological factors on students' learning activities, highlights the importance of statistical thinking from the list of studied factors. The scientist also notes that students' statistical thinking depends on the attitude to statistics, the type of motivation and anxiety statistics.

\section{Materials and methods}

In order to achieve the purpose and objectives outlined in the academic paper, the following methods have been used, namely: 
- Theoretical analysis, description, comparison and synthesis (to study the theoretical fundamentals of the influence of psychological factors on the students' motivation to study at tertiary educational institutions). In particular for: consideration of the students' motivation to study at tertiary educational institutions as an important psychological and pedagogical problem; research on the issues of motivation of educational and professional activities of students of tertiary educational institutions; consideration of psychological factors influencing the students' motivation to study at tertiary educational institutions; analysis of the ways to increase the students' motivation to study at tertiary educational institutions; consideration of psychological factors influencing the level of students' academic performance at tertiary educational institutions; consideration of motivation to study in the context of an important aspect of critical thinking among students of tertiary educational institutions.

- $\quad$ Grouping, measurement, observation and experiment (to study the practical principles of the influence of psychological factors on the students' motivation to study at tertiary educational institutions on the example of individual countries). Based on the investigations conducted at the University of Guilan (Iran), where the study was fulfilled to determine the psychological factors influencing the creativity of students, studying at this institution of tertiary education); the Interior School of Sabah Division (Malaysia), where the study was conducted to determine the impact of three key psychological factors (academic self-efficacy, parental support and psychological well-being) on students' motivation to study); Guaymas, Sonora (Mexico), where the study was conducted to determine the influence of psychological factors on students' motivation to study); National Academies of Sciences, Engineering, and Medicine (the United States of America), where the study was conducted to determine the impact of motives and thinking as key psychological factors on students' academic performance in the context of tertiary education); Inholland University of Applied Sciences (the Netherlands), where the study was conducted, which basic purpose centered around determining the psychological factors influencing the students' motivation to study) as well as submitting a generalized classification of psychological factors, influencing the students' motivation to study at tertiary educational institutions.

The methodological basis of the academic paper is based on the investigations presented by scientists, which have identified the positions of students (the University of Guilan (Iran), the Interior School of Sabah Division (Malaysia), National Academies of Sciences, Engineering, and Medicine (the United States)) regarding the influence of psychological factors on their motivation to study. The present investigation is also based on the study of students' viewpoint concerning the psychological factors, influencing the students' motivation to study. The research also: outlines the correlations between psychological factors and the students' motivation to study at tertiary educational institutions; determines the importance of the influence of psychological factors on the students' academic performance at tertiary educational institutions.

\section{Results and discussion}

Research proves that the motivation of students to study is influenced by numerous factors (reasons). Consequently, the results of a survey conducted on the example of determining the position of foreign students on the basic factors motivating them to study, who receive (or want to obtain) higher education at tertiary educational institutions in Germany have shown the following results. Due to the conducted survey, it has been revealed that one of the most important factors, which are also determined from the standpoint of psychological influence on the choice of obtaining higher education in Germany, are as follows: interest in improving students' own skills, in particular in the framework of mastering the German language; improving the level and quality of life; the choice of the country of study, which is primarily based on the reputation of this country in the global educational environment; the nation's high technology; the potential 
opportunity to stay in this country due to finding a promising place of employment (Survey highlights motivations..., 2019).

Based on the information provided by StudyPortals (Ten psychological and biological..., 2020), the important psychological factors influencing the academic performance of students of tertiary educational institutions are as follows: chosen learning strategy, according to which students decide how to acquire knowledge: at the surface level or at the deep level; self-regulating ability, which affects the level of academic achievement; self-directed studying, through which students have the opportunity to determine their own learning needs and make decisions about further learning strategies; self-assessment, which affects the level of student achievement; selfefficacy, which determines the ability of students to study successfully; motivation, which is also divided into internal motivation (it determines the student's internal desire to study and acquire new knowledge, skills and abilities) and external motivation (it determines the student's desire to study through the desire to obtain a certain reward) (Malyshkin \& Halimon, 2018).

For instance, at school, the success of students' studying depends on such psychological factors as self-discipline, thinking and motivation. This also applies to students pursuing higher education at tertiary educational institutions. The investigations show that thinking or in other words - intelligence should be considered as one of the important psychological categories. Such concept as "fixed thinking" is also distinguished in psychological science. People, including students, with "fixed thinking" have low levels of productivity, because success and failure in such a situation reflect a level of ability that cannot be changed (The Quest for a Good Life, 2020). In the matter of self-discipline, this psychological factor is one of the most decisive, the impact of which affects the level of effectiveness of students' learning. At the same time, motivation acts as an influencing factor due to which it is possible to find an explanation of the student's experience in the educational process, in particular, the features of his interests (The Quest for a Good Life, 2020).

From the perspective of the investigations presented by K.O. Chechelj (2011), it should be noted that currently increasing the students' motivation to study at tertiary educational institutions is possible through the effective implementation of one of the following methods:

to use information technologies in the educational process (this will contribute to the formation of students' information culture as well as form a situation of success; as a result, it will increase students' motivation to study);

conducting investigations on the basis of substantive and practical components, that is, for instance, the use of the project method in conjunction with computer technologies (this will make it possible for students - future specialists to professionally master innovative technologies in the context of their professional activities in the future);

involvement of students to participate in competitions (this will develop students' ability to think intuitively, expand the skills of creative, mental and productive activities);

- $\quad$ involvement of students to participate in scientific and practical conferences (this will make it possible for students to better assess and see a way out of current problems of personal development; it will promote the formation of practical experience, self-development, selfknowledge, self-assessment);

involvement of students to participate in the students' scientific society (this will contribute to the formation and development of students' professional competences, organizational and communicative qualities).

The University of Guilan (Iran) has also conducted the research in order to determine the psychological factors influencing the creativity of students studying at this institution of tertiary education. Half of the surveyed students (namely 50\%) have noted that such a psychological factor as the psychological atmosphere significantly affects students' studying (Sadeghi \& 
Ofoghi, 2011). The results of the research have proven that in Malaysia, for example, in the Interior School of Sabah Division, in the context of students' survey, three key psychological factors have been identified that affect students' motivation to study. They include academic selfefficacy, parental support and psychological well-being. These three above mentioned factors, in the framework of the processing of questionnaires, filled in by students, act as the most important factors of educational achievements (Gang et al., 2019). In Mexico, in particular in Guaymas, Sonora, the research has also been conducted in order to determine the influence of psychological factors on students' motivation to study. In the course of the investigation it has been established that emotional intelligence, relationships with teachers and classmates, and a focus on happiness affect the attraction of students to research activities at a tertiary educational institution (DuronRamos et al., 2018; Kostruba, 2018a; Kostruba, 2018b).

In the course of the investigation it has been found that the influence of psychological factors is quite effective in the case of motivating students to study. Consequently, National Academies of Sciences, Engineering, and Medicine (the United States of America) conducted a study which has revealed that motives and thinking are two important psychological factors influencing on students' success in the context of studying at the tertiary educational institution. The basic essence of the motive centers around the importance of obtaining higher education, as this is a way to professional development in the future. At the same time, students increase their personal qualities and improve intelligence through thinking (Destin, 2018). In addition to the above mentioned, it is worth paying attention to the factors influencing on students in the context of their desire to obtain higher education abroad. Taking this into consideration, and also relying on a study conducted in the United States of America, it should be noted that the desire of students to study abroad is generally formed due to the influence of motivational achievements, neophilia and migration characteristics ( $\mathrm{Li}$ et al., 2013). The results of the students' survey from one of the colleges of the United States of America have revealed that important psychosocial factors influencing the success of students in the learning process are as follows: academic self-efficacy, organization and attention to learning process, stress and time management, features of students' involvement in college activities, emotional satisfaction (Krumrei et al., 2013).

At the same time, according to the results of another survey of students, studying at another institution of tertiary education, it has been found that the satisfaction of students with university education is influenced by numerous psychological factors. Consequently, interpersonal communication as one of the psychological factors of influence contributes to the adaptation of students to the tertiary educational institution. In addition to interpersonal communication, the satisfaction of students with university education, including the formation of motivation to study, is influenced by the emotional environment of students as well as socialpsychological adaptation to the educational process (Role of socio-psychological..., 2018). Thus, based on the information presented above, the generalized classification of psychological factors influencing the students' motivation to study at tertiary educational institutions is reflected in Figure 1.

In the Netherlands, the study has been conducted on the example of students of Inholland University of Applied Sciences, the basic purpose of which cenred around determining the factors influencing the students' motivation to study. The results of studying the position of students have showed that it is psychological factors that have a significant impact on learning process: on the one hand, they stimulate the success of educational activities, and on the other hand, they are the reason for withdrawing from the tertiary educational institution (in particular, it is addiction, fear of failure, depression) (Visser, 2017; Zashchirinskaia, 2020). 


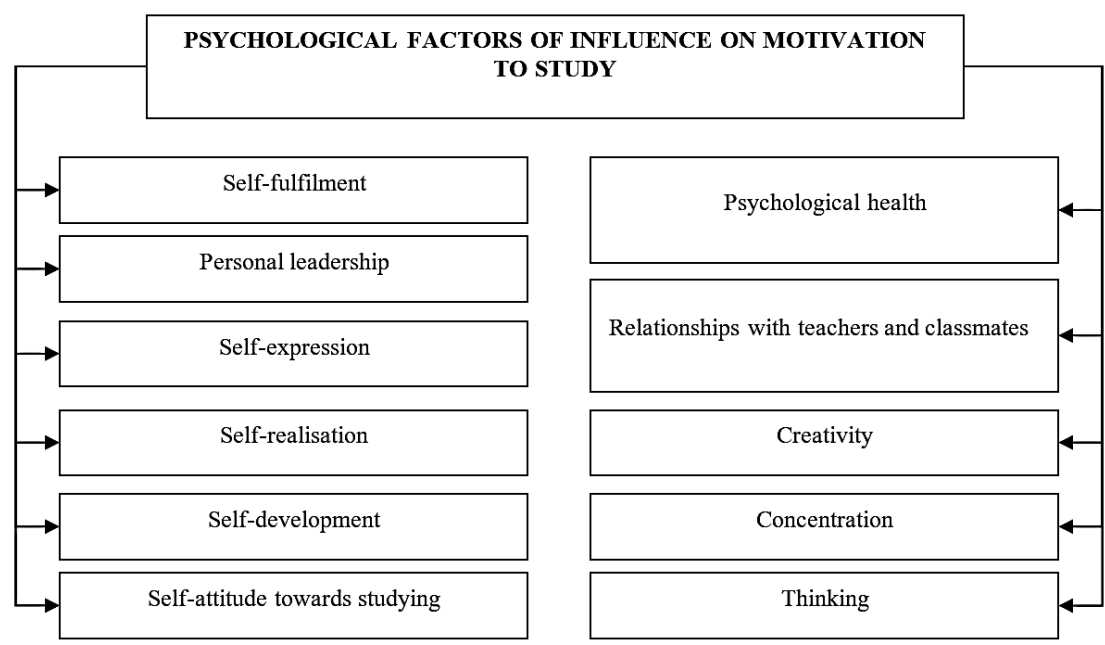

Figure 1. Classification of psychological factors influencing the students' motivation to study at tertiary educational institutions

Source: it has been compiled on the basis of conducted studies

Students of the University of Guilan (Iran) have noted that such a psychological factor as the psychological atmosphere significantly affects the level of their education. In Malaysia, for instance, in the Interior School of Sabah Division, students have identified three key psychological factors that influence their motivation to study, including: academic self-efficacy, parental support and psychological well-being. In Mexico, in particular in Guaymas, Sonora, the results of a study regarding determining the influence of psychological factors on students' motivation to study have established that emotional intelligence, relationships with teachers and classmates, and a focus on happiness influence on students' attraction to academic research activities at tertiary educational institutions. The study conducted by National Academies of Sciences, Engineering, and Medicine (the United States of America) has revealed that motives and thinking are two important psychological factors influencing students' success in the context of studying at the tertiary educational institution. The results of the students' survey from one of the colleges in the United States have shown that important psychosocial factors influencing students' success in the learning process are as follows: academic self-efficacy, organization and attention to studying, stress and time management, features of students' involvement in college, emotional satisfaction (Golub et al., 2020a; Golub et al., 2020b).

The conducted investigations made it possible to note that achievement of success by students in the process of studying depends on clearness and correctness of their acquisition of educational material. This process, as modern practice shows, is influenced by the right tactics and teaching strategy selected by educators. Also, on the basis of the processing of the research's theoretical basis it has been proven that increasing the students' motivation to study is possible through the following ways: a common learning environment in the students' collective; participation of students in discussions, conferences, competitions; work in groups; application of innovative technological methods of studying educational material. Studying the features of the influence of psychological factors on students' motivation to study has shown that the following factors have a significant impact on students' success in the context of obtaining higher education, namely: the proper distribution of time, concentration, stress, anxiety and consultations of teachers. The investigations have proven that the most decisive psychological factors influencing students' motivation to study in German tertiary educational institutions are as follows: interest in improving students' own skills; improving the level and quality of life; the nation's high technologies. 


\section{Conclusions}

Therefore, the results of studying the theoretical and practical principles of the influence of psychological factors on the students' motivation to study at tertiary educational institutions have identified the key psychological factors, positively affecting the educational process of students, as well as the success of their research activities. It has been established that the success of students' research activity, in the context of their acquisition of knowledge at the tertiary educational institution, depends on the individual creative style of scientific activity and on selfrevelation of the potential to study.

In the course of the research it has been determined that the key psychological factors, influencing the students' motivation to study at tertiary educational institutions are as follows: motivational structure; the student's desire to study; self-expression; self-fulfilment of the set goal in educational activity; personal leadership; the level of organization by the student of the features of educational activity; educational and professional environment; relationships with teachers and classmates; self-development; creativity; self-efficacy; openness; self-adherence; selfconfidence; self-perception; special abilities; general intelligence; chosen learning strategy; selfregulating ability; self-assessment; concentration; thinking; self-attitude to studying; psychological health. However, the investigations also have revealed that psychological factors on the one hand stimulate the success of students' learning activities, in the context of their obtaining education at the tertiary educational institution, and, on the other hand, they are the reason for withdrawing from the tertiary educational institution due to addiction, fear of failure, depression.

\section{References}

Alam, G.M., Oke, O.K., Orimogunje, T. (2010). Volumetric analysis and chemistry students' performance: Combined influence of study habit, physiological and psychological factors. Academic Journals, 5(11), 1325-1332.

Beharu, W.T. (2018). Psychological factors affecting students' academic performance among freshman psychology students in Dire Dawa University. Journal of Education and Practice, 9(4), 59-65.

Budianto, L. (2010). Students' psychological factors in SLA: A dilemma for teachers of English. LINGUA Jurnal llmu Bahasa dan Sastra, 5(1), 62-68.

Chechelj, K.O. (2011). Psychological and pedagogical factors motivating students-teachers to research work in higher education. Science and Education, 8, 130-132.

Destin, M. (2018). Leveraging psychological factors: A necessary component to improving student outcomes. Retrieved from: https://www.thirdway.org/report/leveragingpsychological-factors-a-necessary-component-to-improving-student-outcomes.

Duron-Ramos, M.F., Vazquez, F.I.G., Lagares, L.P. (2018). Positive psychosocial factors associated with the university student's engagement. The Open Psychology Journal, 11, 292-300.

Fomenko, K.I. (2015). Motivational factors of self-assessment in student age. Psychology and Personality, 2(8), 163-175.

Gang, G.C.A., Han, C.G., Bansa, L.A. (2019). Contribution of psychological factors on academic achievement of rural students in the Interior School of Sabah Division. International Journal of Education, Psychology and Counseling, 2(27), 76-90.

Golub, G., Kukharets, S., Skydan, O., Yarosh, Y., Chuba, V., Golub, V. (2020a). The optimization of the gasifier recovery zone height when working on straw pellets. International Journal of Renewable Energy Research, 10(2), 529-536.

Golub, G., Skydan, O., Kukharets, V., Yarosh, Y., Kukharets, S. (2020b). The estimation of energetically self-sufficient agroecosystem model. Journal of Central European Agriculture, 21(1), 168-175. 
Hassan, G. (2020). Factors influencing undergraduate students' motivation to study science. Retrieved from: https://conference.pixel-online.net/NPSE/files/npse/ed0003/FP/0094SSE92-FP-NPSE3.pdf.

Kadosh, K.C., Staunton, G. (2019). A systematic review of the psychological factors that influence neurofeedback learning outcomes. Neurolmage, 185(15), 545-555.

Khalimon, E., Brikoshina, I., Guseva, M., Kogotkova, I., Nikitin, S. (2019). National projects as a way to solve the problems of economic and digital disparities in different areas and regions. In: 5th IPMA SENET Project Management Conference (SENET) - Challenges of Growing Economies, pp. 105-111. Belgrade: Serbian Project Management Assoc.

Kortukova, T.O., Dei, M.O., Blahodarnyi, A.M., Kaminska, N.V. (2020). COVID-19: regulation of migration processes in the European legal area. Cuestiones Politicas, 38(66), 321-332.

Kostromina, S.N., Dvornikova, T.A. (2016). Psychological factors of cognitive learning strategies formation in students. Bulletin of St. Petersburg University, Psychology, 4, 110-119.

Kostruba, A.V. (2018a). Law enforcement as a form of realization of right: phenomenological analysis experience (civilized aspect). Revista de Derecho Civil, 5(1), 177-190.

Kostruba, A.V. (2018b). Review of contractual obligations in the Civil Code of Ukraine. Estudios de Derecho, 76(167), 143-160.

Krumrei, E.J., Newton, F.B., Kim, E., Wilcox, D. (2013). Psychosocial factors predicting firstyear college student success. Journal of College Student Development, 54(3), 247-266.

Li, M., Olson, J.E., Frieze, I.H. (2013). Students' study abroad plans: The influence of motivational and personality factors. Frontiers: The Interdisciplinary Journal of Study Abroad, 23(1), 74-89.

Malaspina, Q.M. (2018). Psychological factors associated with academic performance statistics. Retrieved from: https://bit.ly/30GBiKz.

Malyshkin, N., Halimon, E. (2018). Analysis of level of the Russian digital economy development. Vestnik Universiteta. Retrieved from: https://vestnik.guu.ru/jour/article/view/1118

Meljman, V. (2015). Psychological factors of motivation of educational and professional activity of students of higher educational institutions. Retrieved from: https://ojs.kname.edu.ua/index.php/area/article/view/802/744.

Mihaela, P.L. (2015). Psychological factors of academic success. Procedia, Social and Behavioral Sciences, 180, 1632-1637.

Myronets, O.M., Danyliuk, I.V., Dembytska, N.M., Frantsuz-Yakovets, T.A., Dei, M.O. (2020). Current issues and prospects of modern higher legal education in conditions of the fight against COVID-19. Cuestiones Politicas, 37(65), 438-456.

Ponikarovsjka, S.V. (2011). Psychological factors of successful education of students of higher educational institutions. Pedagogical Education: Theory and Practice, 8, 241-245.

Role of socio-psychological factors of satisfaction with education in quality assessment of university. (2018). Retrieved from: https://ukdiss.com/examples/socio-psychologicalfactors-of-satisfaction-with-education.php?vref $=1$.

Sadeghi, A., Ofoghi, N. (2011). The psychological factors affecting students' creativity inside the class (CIC) (case study the University of Guilan, Iran). Procedia Social and Behavioral Sciences, 15, 263-270.

Siljvejstr, A., Mokljuk, M. (2014). Motivation of students' learning as a psychological and pedagogical problem. Scientific Notes. Series: Problems of Methods of PhysicalMathematical and Physical Education, 1(5), 152-158.

Skydan, O. (2009). The agrarian policy of rural employment regulation. Management Theory and Studies for Rural Business and Infrastructure Development, 17, 86-93.

Skydan, O. (2011). Planning for sustainable rural development. Management Theory and Studies for Rural Business and Infrastructure Development, 26, 220-226.

Survey highlights motivations for foreign students in Germany. (2019). Retrieved from: https://monitor.icef.com/2019/08/survey-highlights-motivations-for-foreign-students-ingermany/. 
Ten psychological and biological factors influencing your study results. (2020). Retrieved from: https://bit.ly/2Brb8Tr.

The Quest for a Good Life. (2020). Retrieved from: https://thequestforagoodlife.com/2020/04/15/psychological-factors-in-school-success/.

Ullah, M.I., Sagheer, A., Sattar, T., Khan, S. (2013). Factors influencing students' motivation to learn in Bahauddin Zakariya University, Multan (Pakistan). International Journal of Human Resource Studies, 3(2), 90-108.

Vinichenko, M.V., Melnichuk, A.V., Makushkin, S.A. (2018). Implementation of game methods in the preparation of management personnel. In: 4th international conference on higher education advances (head'18), pp. 373-380. Valencia: Universitat Politécnica de Valencia.

Visser, J. (2017). The influence of psychological factors and self-confidence in study success and dropout. Retrieved from: https://www.inholland.nl/media/17353/m-these-janevisser.pdf.

Zashchirinskaia, O.V. (2020). Patterns of interrelation between perception and understanding of images and texts with different degree of blur. Attention Perception \& Psychophysics, 82(3), 1368-1377. 